\title{
Assessment of success of the Ponseti method of clubfoot management in sub- Saharan Africa: a systematic review
}

\author{
Tracey Smythe ${ }^{1 *}$ (D), Debra Mudariki ${ }^{2}$, Hannah Kuper ${ }^{1}$, Christopher Lavy ${ }^{3}$ and Allen Foster ${ }^{1}$
}

\begin{abstract}
Background: Clubfoot is one of the most common congenital deformities affecting mobility. It leads to pain and disability if untreated. The Ponseti method is widely used for the correction of clubfoot. There is variation in how the result of clubfoot management is measured and reported. This review aims to determine and evaluate how success with the Ponseti method is reported in sub-Saharan Africa.
\end{abstract}

Methods: Five databases were examined in August 2017 for studies that met the inclusion criteria of: (1) evaluation of the effect of clubfoot management; (2) use of the Ponseti method; (3) original study undertaken in sub-Saharan Africa; (4) published between 2000 and 2017. We used the PRISMA statement to report the scope of studies. The included studies were categorised according to a hierarchy of study methodologies and a 27-item quality measure identified methodological strengths and weaknesses. The definition of success was based on the primary outcome reported.

Results: Seventy-seven articles were identified by the search. Twenty-two articles met the inclusion criteria, of which 14 (64\%) reported a primary outcome. Outcomes were predominantly reported though case series and the quality of evidence was low. Clinical assessment was the most commonly reported outcome measure and few studies reported long-term outcome. The literature available to assess success of clubfoot management is characterised by a lack of standardisation of outcomes, with different measures reporting success in 68\% to $98 \%$ of cases.

Conclusion: We found variation in the criteria used to define success resulting in a wide range of results. There is need for an agreed definition of good outcome (successful management) following both the correction and the bracing phases of the Ponseti method to establish standards to monitor and evaluate service delivery.

Keywords: Clubfoot, Congenital talipes equinovarus, Ponseti, Outcome, Evaluation, Treatment, Success, Africa, Sub-Sahara

\section{Background}

Clubfoot, or congenital talipes equinovarus (CTEV), is one of the most common congenital musculoskeletal deformities. Within the Africa region, clubfoot birth prevalence is estimated as $1.11(95 \% \mathrm{CI} 0.96-1.26)$ per 1000 live births [1]. Untreated clubfoot results in pain, physical impairment and can ultimately cause disability [2]. The Ponseti method is widely used for the

\footnotetext{
* Correspondence: tracey.smythe@|shtm.ac.uk

'International Centre for Evidence in Disability, London School of Hygiene \& Tropical Medicine, London, UK

Full list of author information is available at the end of the article
}

management of clubfoot [3]. It consists of two distinct phases, the correction phase and the maintenance phase [4]. The correction phase involves precise manipulation of the foot around the talus to correct the cavus, adductus and varus of the deformity. The manipulation position is held in a long leg plaster of paris cast and the cast is typically changed weekly. A percutaneous tenotomy of the Achilles tendon is usually performed to correct the residual equinus. The maintenance phase involves the use of a foot abduction brace (FAB) for $23 \mathrm{~h}$ a day for three months, followed by nightly use until four to five years of age [5]. 
Many classification systems have been proposed to assess the severity of the clubfoot deformity and to measure the impact of treatment [6]. Ponseti and Smoley [4] based their classification on clinical assessment of ankle dorsiflexion, heel varus, forefoot supination and tibial torsion after treatment. Feet were classified as good, acceptable or poor. Harrold and Walker [7] considered the extent of deformity correction. The Pirani score [8] and the Dimeglio score [9] are two of the most widely used classification systems for clubfoot deformity [10]. The Pirani score is from 0 to 6 where zero is a normal foot and six is the most severe deformity. It is reliable when used by non-specialist health workers [11]. The Dimeglio score has a maximum of 20 points and the deformity is graded as benign, moderate, severe or very severe.

Tools that have been developed to assess function include: assessment of patient satisfaction and pain, gait, heel position and range of motion [12, 13]; a questionnaire designed to measure overall satisfaction, foot appearance, pain and physical limitations [14]; and a detailed assessment of movement quality that requires mobility testing with a goniometer and muscle testing [15], but does not include parent reported outcomes.

There is a need for a standardised approach to report clubfoot treatment outcomes [16-18]. To address this gap, this review aims to investigate the literature and to determine and evaluate how success with the Ponseti method is reported in sub-Saharan Africa.

\section{Methods}

\section{Search strategy}

A systematic literature search was conducted in August 2017 for peer-reviewed articles presenting original research findings on the effect of treatment of clubfoot in children in sub-Saharan Africa. Studies were limited to outcomes of the Ponseti method as this technique is widely accepted as best practice [18]. There was no language restriction. Results are presented according to the PRISMA guidelines [19].

Excerpta Medica Database (EMBASE), Global Health, Medline, Africa Wide Information and African Journals Online were examined for studies meeting the following inclusion criteria: [1] evaluation of the effect of clubfoot management, [2] use of the Ponseti method, [3] original study undertaken in sub-Saharan Africa, and [4] published between 1st January 2000 and 1st August 2017. Concepts were expanded to include related terms and synonyms. A study was excluded if there was no evaluation of treatment, however there was no restriction on type of study to allow a quality assessment review. There was no limitation on age of children and the search was restricted by date (2000-2017) to capture current best practice. Full search terms are presented in Table 1 and
Table 1 Search terms for treatment of clubfoot with the Ponseti method in sub-Saharan Africa

1 clubf??t or club-f??t or (club ADJ1 foot) or (talipes ADJ1 equinovarus) or (talipes ADJ1 equino-varus) or (congenital ADJ1 talipes ADJ1 equinovarus) or (congenital ADJ1 talipes ADJ1 equino-varus) or CTEV

2 Ponseti

3 Country name in sub-Saharan Africa ${ }^{a}$

41 AND 2 AND 3

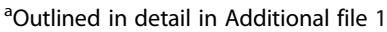

the search terms for the country names are outlined in detail in Additional file 1.

All titles and abstracts were screened independently by two authors (TS and DM). The full paper was reviewed if selected by either author or if the abstract was absent. In addition, the reference lists of the included articles were screened. Consensus was reached through discussion where there was disagreement on eligibility.

\section{Data extraction}

A pilot-tested spread-sheet was used for data extraction from articles that met the inclusion criteria. All characteristics recorded by one author (TS) were reviewed for accuracy by another author (DM). Data extracted included authors, year of publication, type of study, sample size, age of participants, duration of follow up and reported measurement of treatment outcome. Two authors $[20,21]$ were contacted to provide missing information. Where other forms of treatment were detailed or where a paper included a country outside of sub-Saharan Africa, only data regarding the Ponseti method and from the subSaharan African country were extracted.

\section{Assessment of study quality}

Full articles that met the eligibility criteria were categorised according to a hierarchy of study methodologies [22] developed to assess intervention strategies used with children with developmental disabilities. Quality of evidence was ranked as:

I. Systematic review of randomised controlled trials (RCTs); RCT with $N>100$

II. RCT with $N<100$; Systematic review of cohort studies

III.Cohort studies with concurrent control group; Systematic reviews of case control studies

IV.Case series; Cohort study without concurrent control group; Case-control study

V. Expert opinion; Case study or report; Anecdotal Evidence. 
In addition to the levels of evidence, we used a quality measure proposed by Downs and Black [23] to identify methodological strengths and weaknesses of the included studies as there was no limitation on type of study. The quality index is a 27 -item checklist designed for use with both observational studies and randomised controlled trials. The index is comprised of five subscales: reporting (ten questions), external validity (three questions), internal validity (bias and confounding) (13 questions), and power (one question). Items are checked as 'yes', 'partially', 'no' or 'unable to determine' depending on the subscale and higher scores indicating higher quality. The maximum score is 32 .

\section{Data analysis}

The definition of success was determined by the primary outcome reported in the studies or if explicitly stated. There were no studies that were sufficiently homogenous in terms of participants and outcomes to include in a meta-analysis and data were not combined due to methodological and clinical heterogeneity. An integrative review method [15] that included problem identification, data presentation and analysis was used to incorporate results. Summary statistics for the quality measure were calculated and include the mean and range (minimum and maximum).

\section{Results}

\section{Search results}

A total of seventy-seven articles were identified. Twentytwo studies met the inclusion criteria. The search strategy and reasons for excluding articles are presented in Fig. 1.

\section{Study characteristics}

Characteristics of the eligible studies are presented in Table 2 and include children from one day old [21] to 10 years [24].

The quality of evidence that reported outcomes of the Ponseti method in sub-Saharan Africa was low. Studies were included from ten countries in sub-Saharan Africa; studies undertaken in Nigeria and Malawi contributed five papers each. There were three RCTs, all with small sample sizes of less than 100 children. The majority of studies were classed as level IV [22] due to their observational nature.

\section{Definition of success - Primary outcome}

All authors described a form of clinical assessment to assess outcome of treatment. Only 14 studies (64\%) gave a clear definition of success. The Pirani score was defined

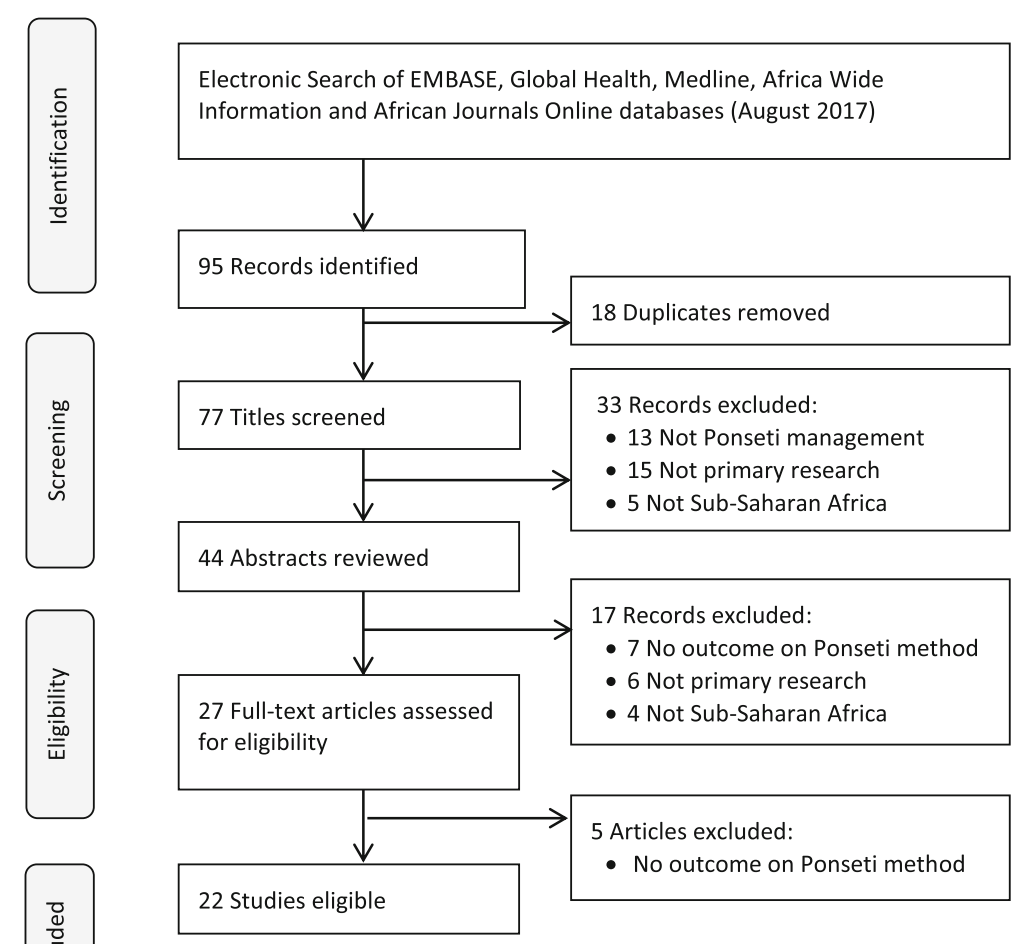

Fig. 1 Search Strategy with PRISMA flow diagram 
Table 2 Characteristics of studies that report outcomes of the Ponseti method in sub-Saharan Africa ${ }^{a}$

\begin{tabular}{|c|c|c|c|c|c|}
\hline $\begin{array}{l}\text { Primary Author } \\
\text { Year Country }\end{array}$ & $\begin{array}{l}\text { Number of children } \\
\text { and (feet) treated }\end{array}$ & Age Range & $\begin{array}{l}\text { Type of study } \\
\text { (Level of Evidence) }\end{array}$ & Comparator Group & $\begin{array}{l}\text { Duration of } \\
\text { Follow up }\end{array}$ \\
\hline $\begin{array}{l}\text { Ibraheem } 2017 \text { [21], } \\
\text { Nigeria }\end{array}$ & $23(14)$ & $<3$ months & $\begin{array}{l}\text { Randomised } \\
\text { controlled trial (II) }\end{array}$ & $\begin{array}{l}\text { Children managed by accelerated Ponseti } \\
\text { treatment }\end{array}$ & 32-77 days. \\
\hline $\begin{array}{l}\text { Malagelada } 2016 \text { [32], } \\
\text { South Africa }\end{array}$ & $65(91)$ & 4-63 months & $\begin{array}{l}\text { Cross sectional } \\
\text { survey (IV) }\end{array}$ & Cases in a UK urban clinic & Not applicable \\
\hline $\begin{array}{l}\text { Smythe } 2016 \text { [35], } \\
\text { Zimbabwe }\end{array}$ & $173(268)$ & $\begin{array}{l}17 \text { days }-5 \text { years } \\
7 \text { months }\end{array}$ & $\begin{array}{l}\text { Case series, } \\
\text { retrospective (IV) }\end{array}$ & Pre-treatment status of cases & $\begin{array}{l}10.2 \text { weeks } \\
(9.5-10.9)\end{array}$ \\
\hline $\begin{array}{l}\text { Boakye } 2016 \text { [38], } \\
\text { Ghana }\end{array}$ & $271(430)$ & $<6$ months & $\begin{array}{l}\text { Case series, } \\
\text { Retrospective (IV) }\end{array}$ & Pre-treatment status of cases & Not reported \\
\hline $\begin{array}{l}\text { Adegbehingbe } 2015 \\
\text { [39], Nigeria }\end{array}$ & $4931(7745)$ & Not reported & Case series (IV) & Pre-treatment status of cases & Not reported \\
\hline $\begin{array}{l}\text { Adewole } 2014 \text { [33], } \\
\text { Nigeria }\end{array}$ & $106(158)$ & 7 days -4 years & $\begin{array}{l}\text { Case series, } \\
\text { prospective (IV) }\end{array}$ & Pre-treatment status of cases & $\begin{array}{l}\text { Mean: } 3 \text { years } \\
\text { (range } 2-4 \text { ) }\end{array}$ \\
\hline $\begin{array}{l}\text { Ayana } 2014[24], \\
\text { Ethiopia }\end{array}$ & $22(32)$ & $2-10$ years & $\begin{array}{l}\text { Case series, } \\
\text { prospective (IV) }\end{array}$ & Pre-treatment status of cases & Not reported \\
\hline $\begin{array}{l}\text { Kouamo } 2014[40] \text {, } \\
\text { Togo }\end{array}$ & $24(41)$ & 17 days -7 years & $\begin{array}{l}\text { Case series, } \\
\text { prospective (IV) }\end{array}$ & Pre-treatment status of cases & Not applicable \\
\hline $\begin{array}{l}\text { Mang'oli 2014, } \\
\text { Kenya }\end{array}$ & $223(361)$ & Mean 23 months & $\begin{array}{l}\text { Cross sectional } \\
\text { survey (IV) }\end{array}$ & Status of cases at previous appointment & One year \\
\hline $\begin{array}{l}\text { Kaseke } 2013 \text { [41], } \\
\text { Zimbabwe }\end{array}$ & $14(20)$ & Mean 7.43 weeks & $\begin{array}{l}\text { Non randomised, } \\
\text { prospective (III) }\end{array}$ & Children managed with Kite technique & 6 weeks \\
\hline $\begin{array}{l}\text { Adegbehingbe } 2012 \\
\text { [42], Nigeria }\end{array}$ & $493(749)$ & Not reported & $\begin{array}{l}\text { Case series, } \\
\text { prospective }(V)\end{array}$ & Pre-treatment status of cases & Not reported \\
\hline $\begin{array}{l}\text { Cashman } 2012 \text { [20], } \\
\text { Malawi }\end{array}$ & $>2000$ & Not reported & Case series (IV) & No comparator & Not reported \\
\hline $\begin{array}{l}\text { Pirani } 2012[43], \\
\text { Uganda }\end{array}$ & 370 & $\begin{array}{l}\text { Majority under } \\
14 \text { weeks }\end{array}$ & $\begin{array}{l}\text { Case series, } \\
\text { prospective (IV) }\end{array}$ & Pre-treatment status of cases & Not reported \\
\hline $\begin{array}{l}\text { Harnett } 2011[44] \text {, } \\
\text { Malawi }\end{array}$ & $21(32)$ & $<2$ months & $\begin{array}{l}\text { Randomised } \\
\text { controlled trial (II) }\end{array}$ & $\begin{array}{l}\text { Children managed by accelerated } \\
\text { Ponseti treatment }\end{array}$ & $\begin{array}{l}\text { Mean } 258 \text { days } \\
\text { (70 to } 348 \text { ) }\end{array}$ \\
\hline $\begin{array}{l}\text { Adegbehingbe } 2010 \\
\text { [25], Nigeria }\end{array}$ & $55(80)$ & $<18$ years & $\begin{array}{l}\text { Randomised } \\
\text { controlled trial (II) }\end{array}$ & Children treated by surgery & $\begin{array}{l}3-36 \text { months } \\
\text { post last cast }\end{array}$ \\
\hline Radler 2010 [45], Mali & 52 & $<1$ year & Case series (IV) & Pre-treatment status of cases & Not reported \\
\hline $\begin{array}{l}\text { Firth } 2009 \text { [30], South } \\
\text { Africa }\end{array}$ & $70(106)$ & $\begin{array}{l}1 \text { day - } \\
40 \text { months }\end{array}$ & $\begin{array}{l}\text { Case series, } \\
\text { retrospective (IV) }\end{array}$ & Pre-treatment status of cases & $\begin{array}{l}\text { Mean: } 2 \text { years } \\
5 \text { months }\end{array}$ \\
\hline $\begin{array}{l}\text { Biruk } 2007 \text { [26], } \\
\text { Ethiopia }\end{array}$ & $55(82)$ & $<6$ months & $\begin{array}{l}\text { Case series, } \\
\text { prospective (IV) }\end{array}$ & Children in different age category & Not reported \\
\hline $\begin{array}{l}\text { Lavy } 2007[28], \\
\text { Malawi }\end{array}$ & $307(482)$ & $<12$ months & $\begin{array}{l}\text { Case series, } \\
\text { retrospective (IV) }\end{array}$ & Pre-treatment status of cases & Not reported \\
\hline $\begin{array}{l}\text { Khan } 2005 \text { [27], South } \\
\text { Africa }\end{array}$ & $(61)$ & Not reported & Case series (IV) & Pre-treatment status of cases & Not reported \\
\hline $\begin{array}{l}\text { Tindall } 2005 \text { [29], } \\
\text { Malawi }\end{array}$ & $75(100)$ & Under 4 years & $\begin{array}{l}\text { Case series, } \\
\text { prospective (IV) }\end{array}$ & Pre-treatment status of cases & $\begin{array}{l}5 \mathrm{ft} \text { followed } \\
\text { for } 12-18 \text { months }\end{array}$ \\
\hline $\begin{array}{l}\text { Mkandawire } 2003 \text { [36], } \\
\text { Malawi }\end{array}$ & 54 & Under 2 years & $\begin{array}{l}\text { Case series, } \\
\text { Prospective (IV) }\end{array}$ & Pre-treatment status of cases & 12 months \\
\hline
\end{tabular}

Ordered by year of publication

as the primary outcome measure to assess the deformity correction in 14 studies. Change in the mean Dimeglio score was evaluated in one study [25] and frequency of initial severity was reported with the Harrold-Walker classification in two studies [26, 27]. Other definitions of primary outcome included: the number of days in casts [21], number of patients treated without extensive surgery [25], a plantigrade foot [24, 28, 29], no residual deformity [30], deformity status compared to previous visits [31] and parent reported outcomes on impact of treatment [32]. Limited definition terms included "complete correction" [26] and "satisfactory outcome" [25]. The approach to reporting severity scores varied (Table 3). 


\section{Process outcomes}

There was wide variation in the measurement of process outcomes. The point in treatment when the number of casts was calculated was either before or after the final post tenotomy cast and was inconsistently described. Studies either reported frequency of tenotomy per child or per foot. Definition of relapse or recurrence of deformity differed in the included studies and technical details were only described in five studies (23\%).

Six studies report on brace use [25, 28, 30-33] with the focus on non-compliance. Non-compliance was not well defined in the studies and varied from $2 \%$ to $44 \%$.

One study assessed parent reported outcomes. The study aimed to determine the impact of the casting and bracing phases of the Ponseti method on the family. Each caregiver completed three questionnaires [32] in order to examine the level of impact that Ponseti treatment had on lives of caregivers and the coping strategies employed.

Reported process outcomes are presented in Table 4.

According to the quality assessment (Additional file 2 outlines the individual study results using the Downs and Black (1998) criteria), the mean quality score of the included studies was 14.8 (5-21).

\section{Reporting}

Reporting was the highest scoring category of the quality assessment. All studies included a clear study hypothesis and aim and the majority $(17 / 22)$ clearly described the characteristics of the patients and the intervention. However, while some distributions of principle confounders were partially described, few studies accounted for confounding in the study design or analysis. Loss to follow up was only reported in half of the studies. Few studies demonstrated a comprehensive attempt to measure adverse effects.

\section{External validity}

Many children were recruited from University and tertiary hospitals or national centres and therefore external validity was limited as the interventions undertaken in a specialist centre are likely unrepresentative of the hospitals most of the source population would attend.

\section{Internal validity - Bias and confounding}

Randomisation is not possible in cohort studies and in the studies where randomisation was used, it was not possible to determine if the intervention assignment was concealed from both parents and staff until recruitment was complete and irrevocable. Characteristics of losses of patient follow up were inconsistently taken into account and reported in seven (32\%) studies. Statistical tests used to assess the main outcomes and why they were chosen were inconsistently described; for example, median, mean and maximum of the number of casts used to achieve correction are reported in different papers. Power calculations were only outlined in three studies.

\section{Discussion}

This literature review comprises results from case series, prospective trials and cross-sectional surveys in subSaharan Africa. There were few comparative studies concerning the Ponseti method in the region and there were no agreed protocols for reporting the results and outcome of treatment. Due to ethical considerations, most trials investigating treatment of clubfoot are not randomised controlled trials (RCTs) but comparisons of treatments or a review of cohort outcomes. Potential sources of bias in observational studies are well documented [34] and whilst systematic reviews of health care interventions most often focus on RCTs, the inclusion of cohort studies in this review highlights the need for quality design and reporting of studies to increase the strength of evidence.

\section{Principal findings and considerations}

A definition of a primary outcome (success) was described in 14 of the 22 studies. Successful outcome ranged from $68 \%$ to $98 \%$ of cases using different definitions in the 14 studies. There was no consensus on how to define a successful outcome of treatment. There was selective reporting of positive results with little detail given to treatment failure [35]. A range of process measures was included in the studies. The mean number of casts required ranged from 4.6 to 8.7 and is likely affected by the point at which the last cast was measured (pre- or post-tenotomy) and the unlimited age range of the review criteria. The studies used different criteria for relapse recognition and management. Two studies reported patient attrition over $30 \%[28,36]$ however the length of follow-up in the majority of studies was short and few data were available on characteristics of children lost to follow up.

Acknowledging the limitations of the available reported papers, this review suggests that the Ponseti method appears to give successful correction of clubfoot during the correction phase when measured by the Pirani score, Dimeglio classification or simple clinical assessment. However, the lack of a consistent measure of success and insufficient follow up of cases restricts the conclusions that can be made about what happens during the bracing phase, be it success, recurrence or loss to follow-up.

\section{Main findings as related to other publications}

The included studies report success in $68 \%$ to $98 \%$ of cases after the correction (casting) phase. In contrast, 
Table 3 Reported Primary Outcome using the Ponseti method in sub-Saharan Africa

\begin{tabular}{|c|c|c|c|c|}
\hline $\begin{array}{l}\text { Primary Author } \\
\text { Year Country* }\end{array}$ & $\begin{array}{l}\text { Clubfoot } \\
\text { severity } \\
\text { assessment }\end{array}$ & Reported Success Measure & Recurrence / relapse & $\begin{array}{l}\text { Additional surgical } \\
\text { intervention }\end{array}$ \\
\hline $\begin{array}{l}\text { Ibraheem } 2017 \\
\text { [21], Nigeria }\end{array}$ & Pirani score & $\begin{array}{l}\text { Number of days in casts, number } \\
\text { of casts applied }\end{array}$ & Not reported & Not reported \\
\hline $\begin{array}{l}\text { Malagelada } \\
2016[32], \\
\text { South Africa }\end{array}$ & Pirani score & Parent reported outcomes & 12\% (8 children) & Not reported \\
\hline $\begin{array}{l}\text { Smythe } 2016 \\
\text { [35], Zimbabwe }\end{array}$ & Pirani Score & $85 \%$ feet; Pirani score $<1$ & Not reported & Not reported \\
\hline $\begin{array}{l}\text { Boakye } 2016 \\
\text { [38], Ghana }\end{array}$ & Pirani Score & $\begin{array}{l}\text { Number of casts to correction. } \\
\text { Correction not defined. }\end{array}$ & Not reported & Not reported \\
\hline $\begin{array}{l}\text { Adegbehingbe } \\
2015 \text { [39], } \\
\text { Nigeria }\end{array}$ & Not reported & $\begin{array}{l}89.7 \% \text { ( } 4426 \text { patients) satisfactory } \\
\text { outcome. Criteria for satisfactory } \\
\text { outcome not defined. }\end{array}$ & 4\% (253 feet, 194 patients) & $3 \%$ \\
\hline $\begin{array}{l}\text { Adewole } 2014 \\
\text { [33], Nigeria }\end{array}$ & $\begin{array}{l}\text { Pirani score and } \\
\text { photograph }\end{array}$ & $\begin{array}{l}\text { 100\%; based on clinical judgement, } \\
\text { Plantigrade functional foot }\end{array}$ & $5.16 \%$ (8 feet) & 6 feet \\
\hline $\begin{array}{l}\text { Ayana } 2014 \\
\text { [24], Ethiopia }\end{array}$ & Pirani score & $\begin{array}{l}28 / 41 \text { good results Good = correction } \\
\text { of all deformities. } 97.8 \% \text { achieved } \\
\text { score of }<3\end{array}$ & 2 patients, 4 feet & 8 children/ (11 feet) \\
\hline $\begin{array}{l}\text { Kouamo } 2014 \\
\text { [40], Togo }\end{array}$ & Not reported & $\begin{array}{l}94 \%(179 / 190) \text { compliant with brace } \\
\text { wear } 93.5 \% \text { no visible discomfort }\end{array}$ & $12.2 \%$ (5 cases) & Not reported \\
\hline $\begin{array}{l}\text { Mang'oli } 2014 \\
\text {, Kenya }\end{array}$ & Pirani score & $\begin{array}{l}\text { Initial correction: } 96.2 \% \text { (152 feet) Initial } \\
\text { correction not defined. }\end{array}$ & Not reported & Not reported \\
\hline $\begin{array}{l}\text { Kaseke } 2013 \\
\text { [41], Zimbabwe }\end{array}$ & Pirani score & $\begin{array}{l}\text { Rate of correction: Pirani score at } 3 \\
\text { weeks and } 6 \text { weeks }\end{array}$ & Not reported & Not reported \\
\hline $\begin{array}{l}\text { Adegbehingbe } \\
2012 \text { [42], Nigeria }\end{array}$ & Pirani Score & $\begin{array}{l}89.7 \% \text { treated successfully. Criteria for } \\
\text { success not defined. }\end{array}$ & Not reported & 3.2\% (16 patients) \\
\hline $\begin{array}{l}\text { Cashman } 2012 \\
\text { [20], Malawi }\end{array}$ & Not reported & $\begin{array}{l}30 \text { children failed treatment } \\
\text { (required more extensive surgery) }\end{array}$ & Not reported & 30 children \\
\hline $\begin{array}{l}\text { Pirani } 2012 \\
\text { [43], Uganda }\end{array}$ & Pirani Score & $\begin{array}{l}\text { Mean score } 5.4 \text { falls to }<2 \text { by cast } 6 \text {. } \\
\text { Primary outcome not defined. }\end{array}$ & Not reported & Not reported \\
\hline $\begin{array}{l}\text { Harnett } 2011 \\
\text { [44], Malawi }\end{array}$ & Pirani Score & $\begin{array}{l}\text { Pirani score change. Median start Pirani: } \\
5 \text { ( } 4 \text { to 6). Median at tenotomy /end } \\
\text { treatment: } 0.5 \text { ( } 0.5 \text { to } 1) \text { Median at } \\
6 \text { months: } 0.5 \text { ( } 0 \text { to } 0.5)\end{array}$ & $\begin{array}{l}\text { No episodes of } \\
\text { recurrence after } \\
6 \text { months }\end{array}$ & $\begin{array}{l}3 \text { patients not } \\
\text { corrected }(7 \%) \\
\text { with Pirani }>1\end{array}$ \\
\hline $\begin{array}{l}\text { Adegbehingbe } \\
2010[25] \\
\text { Nigeria }\end{array}$ & $\begin{array}{l}\text { Dimeglio } \\
\text { classification }\end{array}$ & $\begin{array}{l}96.4 \%(53 / 55 \text { children) = satisfactory } \\
\text { (No recurrence) } 3.6 \%(2 / 55)=\text { fair } \\
\text { (recurrence corrected with casts/FAB) } \\
\text { Nil = poor (recurrence with repeat surgery) }\end{array}$ & $\begin{array}{l}2 \text { had recurrence } \\
\text { between } 4 \text { and } \\
6 \text { months }\end{array}$ & None \\
\hline $\begin{array}{l}\text { Radler } 2010 \\
\text { [45], Mali }\end{array}$ & Not reported & $\begin{array}{l}77 \% \text { ( } 40 \text { children): good or average. } 23 \% \\
\text { (12 children): poor. Primary outcome } \\
\text { not defined. }\end{array}$ & Not reported & Not reported \\
\hline $\begin{array}{l}\text { Firth } 2009 \text { [30], } \\
\text { South Africa }\end{array}$ & Pirani score & $61 \%$ fully corrected without residual deformity & $\begin{array}{l}23 \% \text { (re-plaster } 24 \text { feet) } \\
39 \% \text { ( } 41 \text { feet mild } \\
\text { recurrence) }\end{array}$ & $7 \%$ (7 feet) \\
\hline $\begin{array}{l}\text { Biruk } 2007 \text { [26], } \\
\text { Ethiopia }\end{array}$ & $\begin{array}{l}\text { Harrold-Walker } \\
\text { classification }\end{array}$ & 76.8\% (63 feet) No definition of complete correction. & Not reported & $\begin{array}{l}\text { Not reported for } \\
\text { Ponseti cohort }\end{array}$ \\
\hline $\begin{array}{l}\text { Lavy } 2007[28], \\
\text { Malawi }\end{array}$ & Pirani score & $68 \%$ (327/482) Plantigrade or better & Not reported & $\begin{array}{l}12 \text { children referred } \\
\text { for surgery }\end{array}$ \\
\hline $\begin{array}{l}\text { Khan } 2005 \text { [27], } \\
\text { South Africa }\end{array}$ & $\begin{array}{l}\text { Harrold-Walker } \\
\text { classification }\end{array}$ & 6 failures from 61 feet. Criteria for success not defined. & Not reported & Not reported \\
\hline $\begin{array}{l}\text { Tindall } 2005 \text { [29], } \\
\text { Malawi }\end{array}$ & Pirani score & 98\% plantigrade foot with Pirani score & Not reported & $2 \%$ \\
\hline $\begin{array}{l}\text { Mkandawire } \\
2003 \text { [36], Malawi }\end{array}$ & Pirani score & $\begin{array}{l}\text { Correction of deformity. Success of } \\
\text { correction defined as fitting brace. } \\
\text { Mean Pirani score decreased from } \\
\text { 3.6-0.86 }\end{array}$ & $\begin{array}{l}4 \text { children with untreated } \\
\text { clubfoot, } 5 \text { with complex } \\
\text { and } 7 \text { with teratologic }\end{array}$ & Not reported \\
\hline
\end{tabular}


Table 4 Outcomes of the Ponseti Method reported in sub-Saharan Africa ${ }^{a}$

\begin{tabular}{|c|c|c|c|c|c|c|c|}
\hline \multirow{2}{*}{$\begin{array}{l}\text { Primary Author } \\
\text { (Year) Country }\end{array}$} & \multicolumn{7}{|c|}{ Process Outcomes } \\
\hline & $\begin{array}{l}\text { Average } \\
\text { number } \\
\text { of casts }\end{array}$ & Duration of casts & $\begin{array}{l}\text { Percutaneous } \\
\text { Achilles Tenotomy }\end{array}$ & $\begin{array}{l}\text { Receipt of } \\
\text { braces }\end{array}$ & $\begin{array}{l}\text { Brace } \\
\text { compliance }\end{array}$ & $\begin{array}{l}\text { Loss to } \\
\text { follow up }\end{array}$ & Complications \\
\hline $\begin{array}{l}\text { Ibraheem } \\
\text { (2017 Nigeria }\end{array}$ & 5.43 & 52 days (35-77) & $\begin{array}{l}1 \text { child did not have } \\
\text { tenotomy, not reported } \\
\text { case or control }\end{array}$ & $100 \%$ & Not reported & Nil & $\begin{array}{l}\text { Reported no } \\
\text { complications } \\
\text { with swelling }\end{array}$ \\
\hline $\begin{array}{l}\text { Malagelada } \\
\text { (2016) South } \\
\text { Africa }\end{array}$ & $\begin{array}{l}8.7 \\
\text { (range 1-24) }\end{array}$ & Not reported & $89 \%$ (58 children) & $\begin{array}{l}100 \% \text { due } \\
\text { to inclusion } \\
\text { criteria }\end{array}$ & $\begin{array}{l}2 \% \text { ( } 1 \text { child) } \\
\text { non-compliant }\end{array}$ & $\begin{array}{l}\text { Not } \\
\text { applicable }\end{array}$ & $\begin{array}{l}\text { Defined as } \\
\text { relapse and } \\
\text { non-compliance: } \\
9 \text { children }\end{array}$ \\
\hline $\begin{array}{l}\text { Smythe (2016) } \\
\text { Zimbabwe }\end{array}$ & $7.27(6.7-7.9)$ & $\begin{array}{l}10.2(9.5-10.9) \text { weeks } \\
\text { included tenotomy }\end{array}$ & $\begin{array}{l}78.9 \%(127 / 161 \\
\text { children) }\end{array}$ & Not reported & Not reported & $\begin{array}{l}8.9 \%(17 \\
\text { children) }\end{array}$ & Not reported \\
\hline $\begin{array}{l}\text { Boakye (2016) } \\
\text { Ghana }\end{array}$ & 4.93 & Not reported & $77 \%$ & Not reported & Not reported & $\begin{array}{l}\text { Excluded } \\
\text { from } \\
\text { analysis }\end{array}$ & Not reported \\
\hline $\begin{array}{l}\text { Adegbehingbe } \\
\text { (2015) Nigeria }\end{array}$ & Not reported & Not reported & 77\% (5626 children) & Not reported & Not reported & $\begin{array}{l}\text { Not } \\
\text { reported }\end{array}$ & Not reported \\
\hline $\begin{array}{l}\text { Adweole (2014) } \\
\text { Nigeria }\end{array}$ & $\begin{array}{l}\text { 4.6 (range 3- } \\
\text { 9) }\end{array}$ & $\begin{array}{l}\text { Weekly cast change, } \\
\text { tenotomy } 3 \text { weeks }\end{array}$ & $26.6 \%$ (42 feet) & $\begin{array}{l}56.8 \% \\
\text { (60 patients) }\end{array}$ & $\begin{array}{l}\text { No child with } \\
\text { relapse wore } \\
\text { braces }\end{array}$ & $\begin{array}{l}\text { Not } \\
\text { reported }\end{array}$ & $\begin{array}{l}9 \text { feet: cast } \\
\text { complications, } \\
\text { blisters, ulcers, } \\
\text { skin rash }\end{array}$ \\
\hline $\begin{array}{l}\text { Ayana (2014) } \\
\text { Ethiopia }\end{array}$ & $\begin{array}{l}8 \text { (range 6- } \\
10 \text { ) }\end{array}$ & $\begin{array}{l}\text { Casts changed } \\
\text { every } 2 \text { weeks }\end{array}$ & $\begin{array}{l}63.6 \% \text { (14 children, } \\
21 \text { feet) }\end{array}$ & $\begin{array}{l}100 \% \\
<4 \text { yrs. = FAB } \\
>4 \text { yrs. = ankle } \\
\text { foot orthosis }\end{array}$ & Not reported & 1 patient & $\begin{array}{l}\text { No major } \\
\text { complications }\end{array}$ \\
\hline $\begin{array}{l}\text { Kouamo } \\
\text { (2014) Togo }\end{array}$ & Not reported & Not reported & $82.9 \%$ (34/41 feet) & Not reported & Not reported & $\begin{array}{l}\text { Not } \\
\text { reported }\end{array}$ & Not reported \\
\hline $\begin{array}{l}\text { Mangoli } \\
\text { (2014) Kenya }\end{array}$ & Not reported & Not reported & Not reported & $\begin{array}{l}100 \% \text { of } \\
\text { interviewed } \\
\text { parents }\end{array}$ & $\begin{array}{l}\text { 15\% }(33 / 223) \\
\text { non-compliant } \\
\text { Mean use } 18 \\
\text { months (6-23) }\end{array}$ & $\begin{array}{l}\text { Not } \\
\text { applicable }\end{array}$ & $\begin{array}{l}5 \%(11 / 223) \\
\text { skin lesion }\end{array}$ \\
\hline $\begin{array}{l}\text { Kaseke (2013) } \\
\text { Zimbabwe }\end{array}$ & Not reported & Not reported & Not reported & Not reported & Not reported & $\begin{array}{l}6 \text { feet not } \\
\text { reported } \\
\text { at } 6 \text { weeks }\end{array}$ & Not reported \\
\hline $\begin{array}{l}\text { Adegbehingbe } \\
\text { (2012) Nigeria }\end{array}$ & Not reported & Not reported & Not reported & Not reported & Not reported & $\begin{array}{l}\text { Not } \\
\text { reported }\end{array}$ & Not reported \\
\hline $\begin{array}{l}\text { Cashman } \\
\text { (2012) Malawi }\end{array}$ & Not reported & Not reported & $>80 \%$ & Not reported & Not reported & $\begin{array}{l}107 \\
\text { children }\end{array}$ & Not reported \\
\hline $\begin{array}{l}\text { Pirani (2012) } \\
\text { Uganda }\end{array}$ & Not reported & $\begin{array}{l}\text { Majority corrected } \\
\text { by 6th treatment' }\end{array}$ & Not reported & Not reported & Not reported & $\begin{array}{l}83 \% \\
\text { adherence } \\
\text { rate to end } \\
\text { of casting }\end{array}$ & $\begin{array}{l}\text { Plaster burns } \\
\text { in } 19 / 1000\end{array}$ \\
\hline $\begin{array}{l}\text { Harnett (2011) } \\
\text { Malawi }\end{array}$ & $\begin{array}{l}\text { Median } 5 \text { (4- } \\
\text { 7) }\end{array}$ & $\begin{array}{l}42 \text { days (35-84) } \\
\text { in plaster prior } \\
\text { to tenotomy. }\end{array}$ & $52 \%$ (11 children) & $\begin{array}{l}\text { Given } F A B \\
\text { to wear until } \\
3 \text { years old }\end{array}$ & Not reported & $\begin{array}{l}2 \text { after } \\
\text { plaster. } 1 \\
\text { patient died }\end{array}$ & Not reported \\
\hline $\begin{array}{l}\text { Adegbehingbe } \\
\text { (2010) Nigeria }\end{array}$ & $\begin{array}{l}\leq 6(76.4 \% ; \\
\text { range } 2-6)>6 \\
(23.6 \% \text { range } \\
7-10)\end{array}$ & $\begin{array}{l}2.3-13.7 \\
+/-1.7 \text { weeks }\end{array}$ & $5.5 \%$ (3 children) & Not reported & $\begin{array}{l}\text { Noted as } \\
\text { 'generally good' }\end{array}$ & $\begin{array}{l}\text { None, not } \\
\text { explicitly } \\
\text { mentioned }\end{array}$ & $\begin{array}{l}3.6 \% \text { ugly scar, } \\
\text { recurrence, } \\
\text { blister, infection }\end{array}$ \\
\hline $\begin{array}{l}\text { Radler (2010) } \\
\text { Mali }\end{array}$ & Not reported & Not reported & Not reported & Not reported & Not reported & $\begin{array}{l}\text { Not } \\
\text { reported }\end{array}$ & Not reported \\
\hline $\begin{array}{l}\text { Firth (2009) } \\
\text { South Africa }\end{array}$ & $\begin{array}{l}6.5 \text { (range } \\
2-18 \text { ) }\end{array}$ & Not reported & 74\% (78 feet) & $\begin{array}{l}\text { Received FABs, } \\
\% \text { unspecified }\end{array}$ & $\begin{array}{l}\text { 16\% (11 patients) } \\
\text { non-compliant }\end{array}$ & $\begin{array}{l}\text { Not } \\
\text { reported }\end{array}$ & $\begin{array}{l}8 \% \text { ( } 9 \text { feet) minor } \\
\text { blistering from } \\
\text { braces }\end{array}$ \\
\hline \multirow[t]{2}{*}{$\begin{array}{l}\text { Biruk (2007) } \\
\text { Ethiopia }\end{array}$} & $\begin{array}{l}\text { Maximum } \\
\text { cast } 17 \text { times }\end{array}$ & Weekly cast change & Not reported & $\begin{array}{l}60 \% \text {, average } \\
\text { wait time } \\
3-4 \text { months }\end{array}$ & Not reported & $\begin{array}{l}\text { Not } \\
\text { reported }\end{array}$ & $\begin{array}{l}\text { Not reported for } \\
\text { Ponseti cohort }\end{array}$ \\
\hline & Not reported & Not reported & $37 \%$ had tenotomy & & & & \\
\hline
\end{tabular}


Table 4 Outcomes of the Ponseti Method reported in sub-Saharan Africa ${ }^{a}$ (Continued)

\begin{tabular}{|c|c|c|c|c|c|c|c|}
\hline \multirow{2}{*}{$\begin{array}{l}\text { Primary Author } \\
\text { (Year) Country }\end{array}$} & \multicolumn{7}{|c|}{ Process Outcomes } \\
\hline & $\begin{array}{l}\text { Average } \\
\text { number } \\
\text { of casts }\end{array}$ & Duration of casts & $\begin{array}{l}\text { Percutaneous } \\
\text { Achilles Tenotomy }\end{array}$ & $\begin{array}{l}\text { Receipt of } \\
\text { braces }\end{array}$ & $\begin{array}{l}\text { Brace } \\
\text { compliance }\end{array}$ & $\begin{array}{l}\text { Loss to } \\
\text { follow up }\end{array}$ & Complications \\
\hline $\begin{array}{l}\text { Lavy (2007) } \\
\text { Malawi }\end{array}$ & & & & $\begin{array}{l}44 \% \text { given } \\
\text { FABs }\end{array}$ & $\begin{array}{l}44 \% \text { ( } 145 / \\
327 \text { feet) }\end{array}$ & $\begin{array}{l}32 \% \\
\text { (155 feet) }\end{array}$ & $\begin{array}{l}307 \text { adequate } \\
\text { records }\end{array}$ \\
\hline $\begin{array}{l}\text { Khan (2005) } \\
\text { South Africa }\end{array}$ & Not reported & Not reported & Not reported & Not reported & Not reported & $\begin{array}{l}\text { Not } \\
\text { reported }\end{array}$ & Not reported \\
\hline $\begin{array}{l}\text { Tindall (2005) } \\
\text { Malawi }\end{array}$ & 5.3 & $\begin{array}{l}\text { Mean treatment } \\
9.1 \text { weeks }\end{array}$ & $41 \%$ & All & Not reported & $\begin{array}{l}\text { Not } \\
\text { reported }\end{array}$ & $\begin{array}{l}2 \text { minor } \\
\text { complications }\end{array}$ \\
\hline $\begin{array}{l}\text { Mkandawire } \\
\text { (2003) Malawi }\end{array}$ & $\begin{array}{l}\text { Weekly cast } \\
\text { change }\end{array}$ & $\begin{array}{l}\text { Mean treatment: } \\
7.4 \text { weeks for } \\
\text { idiopathic, } 7.1 \\
\text { weeks for complex }\end{array}$ & Not reported & Not reported & Not reported & $\begin{array}{l}32 \text { patients } \\
(35 \%)\end{array}$ & Not reported \\
\hline
\end{tabular}

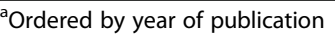

global success rates after the correction phase are cited as approximately $90 \%[18,37]$. Comprehensive tools to assess function (e.g. as described by Laaveg and Ponseti (12), the Roye tool [14], the Bangla tool [13] or the Clubfoot Assessment Protocol (CAP) [15]) are not reported in the studies from sub-Saharan Africa.

\section{Implications of findings}

We found that the differences between study populations, methodology and the way that outcomes are described contribute to the variation in results reported for the Ponseti method in sub-Saharan Africa. Currently, different scores are used for the assessment of clubfoot severity. Standardisation is required to define successful outcome of clubfoot management so that risk factors for good and poor outcome can be determined and services can be monitored and evaluated.

The Pirani score was the most frequent clinical assessment used. It has been validated in younger children and demonstrates acceptable interrater reliability [8]. A short assessment time is required and it is easy to use, however to ensure consistency more guidance would be helpful on how to measure the individual components, as similarly provided by the diagrams and video produced to aid assessment with the Dimeglio score. The Pirani scoring system is the only assessment that has evidence for use by paramedics, and is in our opinion the easiest severity measure to use in young children before walking age.

\section{Methodologic issues}

To our knowledge, this is the first systematic review of outcomes to measure success of the Ponseti method in sub-Saharan Africa. The observation of explicit methodology and lack of language restriction are strengths of this study. The literature available to assess success of clubfoot treatment is characterised by a lack of standardisation of outcomes. Studies routinely use the term "success rates" but do not define a successful outcome. Given that Ponseti management involves both correction and maintenance, the definition of success should always reflect both of these important endpoints and we encourage researchers to measure and report both. Bias in internal validity arose from studies where differences in follow up were regularly ignored, however compliance with the corrective phase of the intervention was generally reported as being good. Studies must include followup or acknowledge the limitations of selecting one part of the treatment process.

The potential for confounding in the reviewed studies to obscure true effects is significant as the majority are observational. Randomisation may be considered unethical in certain circumstances and well designed controlled trials may provide more opportunities to analyse different outcomes. Studies intended to address comparative effectiveness of management for clubfoot should use a careful control for covariates such as unilateral or bilateral clubfoot as disproportionate weighting is given to bilateral cases [17].

\section{Research gaps}

Although a number of studies are available on initial treatment (correction phase) outcomes, very few studies are available on long term outcomes and follow up in the bracing phase, which are essential for measuring success of the entire Ponseti method.

No study compared different scoring systems. A study comparing multiple assessments in the same patient before and after treatment would be of value in assessing the equivalence or superiority of measurement techniques.

Studies need to control for the side of clubfoot and previous treatment, account for loss to follow up and adjust for confounding in methods or analysis in order 
to avoid the shortfalls of the current observational literature.

\section{Recommendations}

Consensus is needed to standardise the reporting of outcomes and how success after Ponseti management is defined. For sub-Saharan Africa the definition needs to be appropriate for use by trained therapists who are managing children with clubfoot. This systematic review contributes to the knowledge about the importance of providing evidence to improve clubfoot services.

\section{Conclusions}

The lack of good quality studies, variation in definition of success and limited follow-up of patients means the success rate of clubfoot treatment using the Ponseti method in sub-Saharan Africa is uncertain. There is need for an agreed definition of good outcome following both the correction and the bracing phase to monitor and evaluate service delivery and identify reasons for poor outcome. It is very important that children who complete the correction phase are followed through the bracing phase and results on success, recurrence and loss to follow up are reported. Studies are also required to document the correlation between clinical outcome, functional outcome and patient/family reported satisfaction.

\section{Additional files}

Additional file 1: Expanded search terms for country name in subSaharan Africa. (DOCX 13 kb)

Additional file 2: Quality index assessment for included studies (studies 1-11 assessed on pages 1-3 and studies 12-22 assessed on pages 4-6). (DOCX $35 \mathrm{~kb}$ )

\section{Abbreviations}

CTEV: Congenital Talipes Equinovarus; FAB: Foot Abduction Brace;

PRISMA: Preferred Reporting Items for Systematic Reviews and Meta-Analyses

\section{Acknowledgements}

Professor Daniel Chandramohan for early concept considerations.

\section{Funding}

The Beit Trust and CBM are gratefully acknowledged for funding provided to TS.

\section{Availability of data and materials}

Data sharing not applicable to this article as no datasets were generated or analysed during the current study. Two web appendices are attached: detailed search terms and quality assessment scores.

\section{Author's contributions}

TS conceived the study. TS AF and CL designed the study protocol. TS and DM searched the literature and extracted data for analysis. TS analysed and interpreted the extracted information. AF CL HK and DM critically revised the manuscript for intellectual content. All authors read and approved the final manuscript.
Ethics approval and consent to participate

Not applicable.

\section{Consent for publication}

Not applicable.

\section{Competing interests}

The authors declare that they have no competing interests.

\section{Publisher's Note}

Springer Nature remains neutral with regard to jurisdictional claims in published maps and institutional affiliations.

\section{Author details}

${ }^{1}$ International Centre for Evidence in Disability, London School of Hygiene \& Tropical Medicine, London, UK. ${ }^{2}$ University of Witwatersrand, Johannesburg, South Africa. ${ }^{3}$ Nuffield Department of Orthopaedics Rheumatology and Musculoskeletal Science, University of Oxford, Headington, UK.

Received: 8 August 2017 Accepted: 7 November 2017

Published online: 15 November 2017

\section{References}

1. Smythe T, Kuper H, Macleod D, Foster A, Lavy C. Birth prevalence of congenital talipes equinovarus in low- and middle-income countries: a systematic review and meta-analysis. Tropical Med Int Health. 2017;22(3):269-85.

2. Pirani S, Naddumba E, Mathias R, Konde-Lule J, Penny JN, Beyeza T, et al. Towards effective Ponseti clubfoot care: the Uganda sustainable clubfoot care project. Clin Orthop Relat Res. 2009;467(5):1154-63.

3. Owen RM, Kembhavi G. A critical review of interventions for clubfoot in low and middle-income countries: effectiveness and contextual influences. J Pediatr Orthop B. 2012;21(1):59-67.

4. Ponseti IV, Smoley EN. The classic: congenital club foot: the results of treatment. Clin Orthop Relat Res. 2009;467(5):1133-45.

5. Desai L, Oprescu F, DiMeo A, Morcuende JA. Bracing in the treatment of children with clubfoot: past, present, and future. lowa Orthop J. 2010:30:15-23.

6. Wainwright AM, Auld T, Benson MK, Theologis TN. The classification of congenital talipes equinovarus. J Bone Joint Surg Br. 2002;84(7):1020-4.

7. Harrold AJ, Walker CJ. Treatment and prognosis in congenital club foot. J Bone Joint Surg Br. 1983;65(1):8-11.

8. Pirani $S$, Hodges D, Sekeramayi F. A reliable and valid method for assessing the amount of deformity in the congenital clubfoot deformity. Journal of Bone \& Joint Surgery, British Volume. 2008;90-B(SUPP I):53.

9. Dimeglio A, Bensahel H, Souchet P, Mazeau P, Bonnet F. Classification of clubfoot. J Pediatr Orthop B. 1995:4(2):129-36.

10. Gao R, Tomlinson M, Walker C. Correlation of Pirani and Dimeglio scores with number of Ponseti casts required for clubfoot correction. J Pediatr Orthop. 2014;34(6):639-42.

11. Shaheen S, Jaiballa H, Pirani S. Interobserver reliability in Pirani clubfoot severity scoring between a paediatric orthopaedic surgeon and a physiotherapy assistant. Journal of Pediatric Orthopaedics-Part B. 2012;21(4):366-8.

12. Laaveg S, Ponseti I. Long-term results of treatment of congenital club foot. J Bone Joint Surg. 1980;62

13. Evans AM, Perveen R, Ford-Powell VA, Barker S. The Bangla clubfoot tool: a repeatability study. Journal of Foot and Ankle Research. 2014;7(1):1-6.

14. Roye B, Vitale M, Gelijns A, Roye D. Patient-based outcomes after clubfoot surgery. Journal of Pediatric Orthopaedics January/February. 2001;21(1):42-9.

15. Andriesse $H$, Hägglund $G$, Jarnlo G-B. The clubfoot assessment protocol (CAP); description and reliability of a structured multi-level instrument for follow-up. BMC Musculoskelet Disord. 2005;6

16. Zhao D, Li H, Zhao L, Liu J, Wu Z, Jin F. Results of clubfoot management using the Ponseti method: do the details matter? A systematic review. Clinical Orthopaedics \& Related Research. 2014;472(4):1329-36.

17. Gray KPV, Gibbons P, Little D, Burns J. Interventions for congenital talipes equinovarus (clubfoot). Cochrane Database Syst Rev. 2014;8

18. Jowett CR, Morcuende JA, Ramachandran M. Management of congenital talipes equinovarus using the Ponseti method: a systematic review. Journal of Bone \& Joint Surgery - British Volume. 2011;93-B(9):1160-4.

19. Liberati A, Altman DG, Tetzlaff J, Mulrow C, Gotzsche PC, loannidis JP, et al. The PRISMA statement for reporting systematic reviews and meta-analyses 
of studies that evaluate healthcare interventions: explanation and elaboration. BMJ. 2009;339:b2700.

20. Cashman J, Sakala H, Hansen L, Mayo A. Lessons and results from the first three years of the Malawi national clubfoot program. Journal of Pediatric Orthopaedics Part B. 2012;21(1):90.

21. Ibraheem G, Adegbehingbe O, Babalola O, Agaja S, Ahmed B, Olawepo A et al. Evaluation of an accelerated Ponseti protocol for the treatment of talipesequinovarus in Nigeria. East and Central African Journal of Surgery. 2017;22(1):28-38.

22. Wiart L, Kolaski K, Butler C, Vogtle L, Logan LR, Hickman R, et al. Interrater reliability and convergent validity of the American Academy for cerebral palsy and developmental medicine methodology for conducting systematic reviews. Dev Med Child Neurol. 2012;54(7):606-11.

23. Downs SH, Black N. The feasibility of creating a checklist for the assessment of the methodological quality both of randomised and non-randomised studies of health care interventions. J Epidemiol Community Health. 1998; 52(6):377-84

24. Ayana B, Klungsoyr PJ. Good results after Ponseti treatment for neglected congenital clubfoot in Ethiopia. A prospective study of 22 children (32 feet) from 2 to 10 years of age. Acta Orthop. 2014;85(6):641-5.

25. Adegbehingbe OO, Oginni LM, Ogundele OJ, Ariyibi AL, Abiola PO, Ojo OD. Ponseti clubfoot management: changing surgical trends in Nigeria. lowa Orthop J. 2010;30:7-14.

26. Biruk WL. Management of club-foot at Tikur Anbessa hospital; Addis Ababa, Ethiopia. East and Central African Journal of Surgery. 2007;12(1):24-9.

27. Khan SA. Ponseti method of treatment of clubfoot in South Africa. Journal of Bone \& Joint Surgery British. 2005;2005:273.

28. Lavy CB, Mannion SJ, Mkandawire NC, Tindall A, Steinlechner C, Chimangeni $\mathrm{S}$, et al. Club foot treatment in Malawi - a public health approach. Disabil Rehabil. 2007;29(11-12):857-62.

29. Tindall AJ, Steinlechner CW, Lavy CB, Mannion S, Mkandawire N. Results of manipulation of idiopathic clubfoot deformity in Malawi by orthopaedic clinical officers using the Ponseti method: a realistic alternative for the developing world? J Pediatr Orthop. 2005;25(5):627-9.

30. Firth $\mathrm{G}$, Eltringham $\mathrm{M}$, Shnier $\mathrm{G}$. Early results of the Ponseti technique for a clubfoot clinic in South Africa. SA Orthopaedic Journal. 2009(Summer ):67-71.

31. Mang'oli P, Theuri J, Kollmann T, MacDonald NE. Ponseti clubfoot management: experience with the Steenbeek foot abduction brace. Paediatr Child Health. 2014;19(10):513-4.

32. Malagelada F, Mayet S, Firth G, Ramachandran M. The impact of the Ponseti treatment method on parents and caregivers of children with clubfoot: a comparison of two urban populations in Europe and Africa. J Child Orthop. 2016;10(2):101-7.

33. Adewole O, Williams O, Kayode M, Shoga M, Giwa S. Early experience with Ponseti Club foot management in Lagos, Nigeria. East and Central African Journal of Surgery. 2014;19(2):72-7.

34. O’Neil M, Berkman N, Hartling L, Chang S, Anderson J, Motu'apuaka M, et al. Observational evidence and strength of evidence domains: case examples. Systematic Reviews. 2014;3(1):35.

35. Smythe T, Chandramohan D, Bruce J, Kuper H, Lavy C, Foster A. Results of clubfoot treatment after manipulation and casting using the Ponseti method: experience in Harare. Zimbabwe Trop Med Int Health. 2016;21(10):1311-8.

36. Mkandawire NC, Chipofya E, Likoleche G, Phiri M, Katete L. Ponseti technique of correcting idiopathic clubfoot deformity. Malawi Med J. 2003;15(3):99-101.

37. Radler $\mathrm{C}$. The Ponseti method for the treatment of congenital club foot: review of the current literature and treatment recommendations. Int Orthop. 2013;37(9):1747-53.

38. Boakye H, Nsiah A, Thomas A, Bello Al. Treatment outcome of Ponseti method in the Management of Club Foot at Komfo Anokye teaching hospital, Ghana: a retrospective study. Archives of Current Research International. 2016;3(2):1-8.

39. Adegbehingbe O, Cook T, Parker E, Morcuende J. Clubfoot disability: Nigeria model for sustainable health system program.. 36th SICOT Orthopaedic World Congress; Guangzhoa, China 2015. p. Abstract No 41660.

40. Kouamo El II, Doumbouya N, Nour M, Nimpa TP, Gnassingbe JP, Moh E, et al. Pirani scoring in the evaluation of the morphological results of congenital Falipes Equinovarus taken care by the Ponseti method. Medecine d'Afrique Noire. 2014;61(6):335-41.

41. Kaseke F, Mudawarima T. Comparison of Ponseti and Kite's method of treatment for congentiral Talipes Equino using the Pirani scoring system. Cent Afr J Med. 2013;59(1-4):14-8.
42. Adegbehingbe OO, Akintayo OA, Morcuende JA. Predicitve factors for Ponseti clubfoot technique practitioners in Nigeria. In:International Society of Orthopaedic Surgery and Traumatology Annual Meeting. 2012.

43. Pirani S, Mathias R, Naddumba E. Ponseti clubfoot treament by orthopaedic officers: prospective cohort study in Uganda. Journal of Pediatric Orthopaedics Part B. 2012;21(1):89-90.

44. Harnett P, Freeman R, Harrison WJ, Brown LC, Beckles V. An accelerated Ponseti versus the standard Ponseti method: A prospective ransomised controlled trial Journal of Bone \& Joint Surgery - British Volume 2011;93B(3):404-408.

45. Radler C, Gubba J, Helmers A, Kraus T, Salzer M, Waschak K. Mali clubfoot project - Experiences, problems and obstacles after two years Journal of Bone \& Joint Surgery - British Volume. 2010;92-B Suppl(4):599.

\section{Submit your next manuscript to BioMed Central and we will help you at every step:}

- We accept pre-submission inquiries

- Our selector tool helps you to find the most relevant journal

- We provide round the clock customer support

- Convenient online submission

- Thorough peer review

- Inclusion in PubMed and all major indexing services

- Maximum visibility for your research

Submit your manuscript at www.biomedcentral.com/submit
C Biomed Central 